\title{
UK watchdog boosts science credentials
}

[LONDON] The gap between science and politics has narrowed slightly with the news that virtually all members of the new Select Committee on Science and Technology of Britain's House of Commons have qualifications in either science or engineering.

Indeed, some are arguing that the balance on the committee may have gone too far. In the previous Parliament, although most committee members had such qualifications, they were tempered by several nonscientists, primarily lawyers.

The five $\mathrm{PhDs}$ on the 11-member, allparty committee include the new chairman, Michael Clark (Conservative, Rayleigh), who took his doctorate at the University of Cambridge and started his career as a research scientist with the chemicals company ICI. He entered parliament in 1983.

Two of the other doctorates are held by Labour MPs who were members of the select committee in the previous parliament: Lynne Jones (Birmingham Selly Oak) in biochemistry and Alan Williams (Carmarthen East and Dinefwr), who holds a first-class honours degree in chemistry from the University of Oxford and later became a lecturer in environmental sciences at Trinity College in Carmarthen.

The remaining two PhDs are newly elected. Ian Gibson, formerly dean of biological science at the University of East Anglia, won the seat of Norwich North with an 11 per cent swing from the Conservatives, and Ashok Kumar, a chemical engineer specializing in fluid dynamics, who formerly worked for British Steel, won Middlesbrough South and

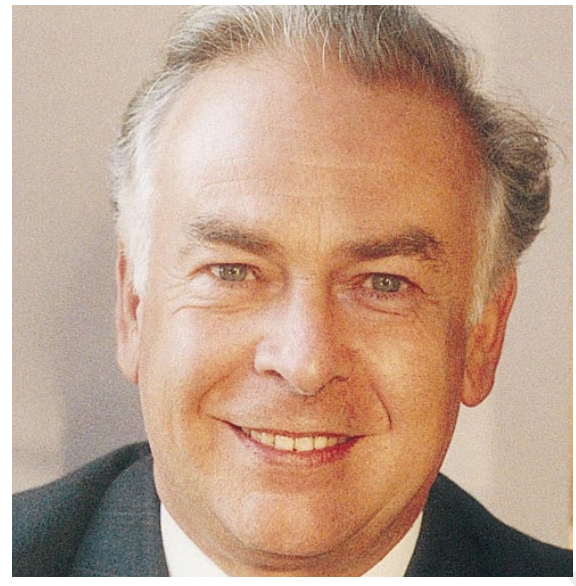

In the chair: Michael Clark, the new chairman of the House of Commons' science committee, is one of five of its members who have a doctorate.

Cleveland East for Labour, having fleetingly been MP for Langbaurgh before the 1992 election.

Other new members of the select committee include Nigel Beard (Labour, Bexleyheath and Crayford), formerly a group research and development manager at ICI; Caroline Spelman (Conservative, Meriden), a food and biotechnology consultant; and Nigel Jones (Liberal Democrat, Cheltenham), formerly a computer programmer.

The expertise of the members means that they should, at least in principle, strengthen the committee's ability to fulfil its mandate to examine the "expenditure, policy and administration of the Office of Science and Technology and its associated public bodies".
Last month, the committee announced its first two inquiries. One will be into the review of further and higher education by the committee headed by Sir Ron Dearing (see Nature 388, 413; 1997); the second will examine potential problems faced by computers in the transition to the year 2000.

Some members of the committee are keen that it should play a key role not only in cross-examining government ministers and civil servants but also in pushing for new policy initiatives. "There may even be a need for a new white paper [policy document] on science," says Gibson, who stresses the need to raise the political profile of science in all major policy decisions.

The growing representation of scientists in parliament has generally been welcomed. "It seems to be an excellent thing," says Valerie Ellis, deputy general secretary of the Institution of Professional Managers and Specialists, the labour union that represents many government-employed scientists.

But others say that a scientific background does not necessarily provide the skills or knowledge to address hot political issues associated with research - for example, the patenting of genetic discoveries.

"It would be a pity if the views of the research community were to dominate the activities of the committee, which must be able to take lay perspectives into account," says one observer. "It's good that there is a strong presence on the committee of people who understand science and technology, but one might have preferred a slightly better balance."

DavidDickson

\section{Management problems prompt Canadian utility to shut reactors}

[MONTREAL] Ontario Hydro, the largest power utility company in North America, is to close seven of its 19 Candu heavy-water nuclear reactors following an internal report that has heavily criticized the management of its nuclear division.

The company's president and chief executive officer, Allan Kupcis, has resigned, and its board has approved a major overhaul of its production facilities estimated to cost between $\mathrm{C} \$ 5$ billion and C $\$ 8$ billion (US\$3.6 billion to US $\$ 5.75$ billion) over the next four years.

William Farlinger, Ontario Hydro's chairman, admitted last week that management practices appeared to have been deteriorating for the past 10 years. $\mathrm{He}$ said that the nuclear unit operated in the early years as "some sort of special nuclear cult”. Farlinger said: “I don't think anybody understood the level to which our nuclear management had sunk."

Nuclear officials are keen to point out that the report emphasizes that the problems lay with management, rather than with the technology. But Gary Kugler, vice-president for commercial operations at Atomic Energy of Canada (AECL), the company that designed and built the Candu reactors, said: "This is not welcome news."

AECL is planning to submit a proposal next month to sell two or more of its reactors to Turkey, and the company is trying to increase its sales to China, South Korea and Romania, which already have Candus. Indonesia, Vietnam, Thailand and the Philippines are also potential customers.

AECL officials are having to reassure such countries that the problems that led to the Canadian shutdown are not typical of the Candus.

Last year, nuclear power provided about 54 per cent of Ontario's electricity, down from 60 per cent or more several years earlier. In 1987, Ontario had six of the ten top-ranked nuclear reactors in the world, but their problems have been growing in recent years. In 1983, a ruptured pressure tube at the Pickering plant cost about C\$1 billion to repair - more than the station's original cost.

Last December, the Atomic Energy Control Board, the nuclear regulator, produced a highly critical report on Ontario Hydro and gave the Pickering station an operating licence for only six months. In January, Kupcis brought in US nuclear experts to take over the utility's nuclear operations and report on its problems (see Nature 385, 287; 1997). It was their report that led to his resignation.

It is not clear whether all the reactors that are being shut down will eventually reopen. Those that do reopen will require upgrades, and any reactors that are closed permanently will have to be replaced by more expensive fossil-fuel plants.

David Spurgeon 